\title{
ARTICLES
}

Submitted 04.26.2019. Approved 11.25.2019

Evaluated through a double-blind review process. Scientific Editor: Pablo Isla

Original version

DOI: http://dx.doi.org/10.1590/So034-759020200302

\section{ROLE OF EMPOWERMENT AND IDENTIFICATION WITH WORK TEAMS IN INNOVATION CLIMATE}

\author{
O papel do empoderamento e da identificação de equipes de trabalho em \\ clima de inovação
}

\author{
El rol del empoderamiento e identificación de equipos de trabajo en clima de \\ innovación
}

\begin{abstract}
Several studies argue that an organizational climate oriented to promote innovation generates greater competitiveness in companies. However, very few researchers have explored the factors that lead to the formation of innovation climate and their effects on workers' performance. Based on a sample of 201 workers from manufacturing and service companies, an analysis was carried out to examine the influence of variables like empowerment and Identification with work teams in innovation climate. Furthermore, the influence of innovation climate on job performance and work commitment was analyzed. The results indicate that there is a positive relationship among the variables of the hypotheses, empowerment and Identification with work teams influence in innovation climate, and the latter influences work performance and work commitment
\end{abstract}

KEYWORDS | empowerment, Identification with work teams, innovation climate, job performance, work commitment

\section{RESUMO}

Vários estudos argumentam que um clima organizacional orientado para promover a inovação gera maior competitividade nas empresas; no entanto, poucos autores exploraram os fatores que condicionam a formação do clima de inovação e os efeitos que estes têm sobre o desempenho do trabalhador. Com base em uma amostra de 201 trabalhadores que atuavam em empresas de manufatura e serviços, foi realizada uma análise sobre a influência de variáveis como empoderamento e identificação de equipes de trabalho no clima de inovação. Também foi analisada a influência do clima de inovação no desempenho laboral e no compromisso de trabalho. Os resultados indicaram que existe uma relação positiva entre as hipóteses levantadas, 0 empoderamento e a identificação com as equipes de trabalho influenciam o clima da inovação, e este último influencia o desempenho e o comprometimento do trabalho

PALAVRAS-CHAVE / Empoderamento, identificação das equipes de trabalho, clima de inovação, desempenho no trabalho, comprometimento no trabalho.

\section{JHONY OSTOS²}

jostos@esan.edu.pe

ORCID: 0000-0003-1888-7378

\section{ARTURO RODOLFO SAENZ} ARTEAGA ${ }^{2}$

asaenz@esa.edu.pe ORCID: 0000-0002-4240-480X

${ }^{1}$ Universidad de Lima, Facultad Ingenieria Industrial, Lima, Perú

2Universidad ESAN, Facultad Ciencias Económicas y administrativas, Lima, Perú

\section{RESUMEN}

Diversos estudios sostienen que un clima organizacional, orientado a promover la innovación, genera mayor competitividad en las empresas; sin embargo, pocos autores han explorado los factores que condicionan la formación del clima de innovación y los efectos que estos tienen en el desempeño del trabajador. En base a una muestra de 201 trabajadores que se desempeñaban en empresas de manufactura y servicios, se llevó a cabo un análisis sobre la influencia de las variables empoderamiento e identificación de los equipos de trabajo en el clima de innovación. También, se analizó la influencia del clima de innovación en el desempeño laboral y en el compromiso de trabajo. Los resultados indicaron que existe una relación positiva entre las hipótesis planteadas, el empoderamiento y la identificación con los equipos de trabajo influyen en el clima de innovación, y este último influye en el desempeño laboral y el compromiso laboral

PALABRAS CLAVE I Empoderamiento, identificación de los equipos de trabajo, clima de innovación, desempeño laboral, compromiso de trabajo. 


\section{INTRODUCTION}

A climate oriented to innovation will allow workers to improve their ability to generate and implement creative ideas that will improve the performance of organizations (King, De Chermont, West, Dawson \& Hebl, 2007). Organizational innovation management not only promotes the creation of favorable organizational climates for innovation, but also fosters a better environment for making decisions on adoption, implementation, and evaluation of innovation (Sánchez, Quintero, Sánchez, Fierro, \& García, 2017).

Due to the limited research on organizational climate oriented to innovation (Gonzales-Roma \& West, 2004), it is necessary to analyze the factors that lead to the formation of innovation climate in companies. Innovation climate is expected to allow workers to develop adaptation or improvement mechanisms in the work processes that influence organizational performance (King et al., 2007). A culture of innovation can generate the capacity for innovation and competitiveness of organizations and thus, it is necessary to define the tools for workers' adaptation based on the needs of respective organizations (Souto, 2015). Innovation is sustained through knowledge management, but there is a gap in the analysis of the factors affecting the abovementioned variables (Bhatnagar, 2014).

The identification of workers with their work teams has significant effects on learning and performance, (Van Der Vegt \& Bunderson, 2005). However, very few empirical studies explain how the identification of workers with their work teams can influence commitment to innovation (Dutton, Dukerich, \& Harquail, 1994).

An important factor for innovation is the empowerment of workers, which is associated with increased innovation (Yang \& Konrad, 2011). Successful innovation requires the development and implementation of ideas that are new to the organization (Kilgour, 2006). High level of worker participation in decisions will generate greater potential for innovation (Yang \& Konrad, 2011). The empowerment of workers has the potential to create the capacity for innovation in companies (Bhatnagar, 2014; Cakar \& Erturk, 2010). However, it is necessary to continue with research on practices that companies should use to generate an adequate climate of innovation (Mol \& Birkinshaw, 2009).

Thompson and Heron (2005) and Collins and Smith (2006) concluded that high-commitment HR management practices contribute to the creation of a climate, where employees workers are willing to share knowledge and, above all, generate commitment for knowledge management. Therefore, it is necessary to analyze the workers' commitment and their identification with the organization to create knowledge. For organizations to survive and compete in a turbulent and changing world, human resources must possess a spirit of creativity and innovation (Yasini, 2016). The companies that are successful with knowledge management are those that are capable of generating a high level of commitment from their workers (Alvesson, 2002).

Research on workers' performance indicates that innovation management is positively associated with the organization's performance and the path of productivity growth (Mol \& Birkinshaw, 2009). Nevertheless, the analysis of the results of innovation management continues to be considered as future lines of research (Vaccaro, Jansen, Van Den Bosch \& Volberda, 2012).

There are several approaches to exploring innovation climate. According to Isaksen (2007), one way of doing this is through a systemic approach from different perspectives and in different contexts. Ekvall (1996) argues that innovation climate is related to different organizational variables, that is, the types of organizational resources that have an influence on the formation of innovation climate and their consequent influence on the results of the organization's operations, and analyzes it from the perspective of organizational process. Recent studies have explored new climate relationships, such as work commitment (Ancarani, Mauro, \& Giammanco, 2019), empowerment (Tan \& Ho, 2015), and work teams (Isaksen \& Lauer, 2002). As researchers are interested in identifying the variables related to climate, it is necessary to continue to pursue this line of research. In this study, a new model is, which includes the variables work commitment, empowerment, work teams, and job performance, was developed and analyzed using the systemic approach as proposed by Isaksen (2007) and the organizational approach as proposed by Ekvall (1996).

Based on the works of the various authors mentioned above this study analyzes the variables that influence innovation climate as well as the variables that are influenced by the innovation climate. The former includes empowerment and identification of with work teams, while the latter includes job performance and work commitment. The model and hypotheses of the study were verified through the analysis of structural equations.

\section{THEORETICAL FRAMEWORK}

\section{Innovation climate}

Innovation climate is the environment in which organizational culture develops and it can be identified through the perception of workers. Some traditional authors, such as Barney (1986), 
argue that a culture oriented to innovation is fundamental for the commitment of workers, who promote new ideas and changes that cannot be easily imitated, thus contributing to competitive advantage.

The strength of organizational climate depends on the level of homogeneity of workers' perceptions, values, and management practices approved by the organization (Miron, Erez, \& Naveh, 2004). When the culture and climate of an organization support innovation, it is rewarded in terms of better performance of innovation practices (West, 2002). Organizational climate is a variable that intervenes in the environment of an organization and behavior of workers (Patterson et al., 2005). An organization could improve its innovation climate by creating incentives for organizational improvement (Lin, Ho, \& Lu, 2014).

Innovation climate promotes formal and informal organizational practices with creative process that guide and support a proactive and persistent approach to work. Regarding the creative process, there are still areas that need to be explored for solutions that benefit organizations in terms of innovation, competitiveness, productivity, and business growth (Barreto \& Petit, 2017).

The maintenance of an organizational climate that favors creation and implementation of ideas and/or processes is related to the performance of organizations (King et al., 2007). An organizational climate that encourages support, cohesion, and intrinsic recognition favors the perception of support for innovation (Montes, Moreno, \& Fernández, 2004). In the same way, a climate that favors innovation is an important support for innovation management and performance of work teams (Bain, Mann, \& Pirola-Merlo, 2001).

A climate conducive to innovation can allow workers to develop new mechanisms for the improvement of work-related processes. Organizations can improve their performance, to the extent that they alleviate the negative consequences of work demand, by maintaining a good innovation climate (King et al., 2007).

\section{Empowerment}

Empowerment is defined as a process that extends feelings of trust and control through the participation of workers in decision-making. This leads to better results in self-efficacy and performance (Eylon, 1998). Likewise, leadership as a true facilitator of innovation (Friedrich \& Zhong, 2017) is an essential factor that contributes to the innovation capacity of an organization (Arguello \& Quintanilla, 2017).
At the same time, empowerment is a set of activities aimed at strengthening confidence in workers' capabilities. The objective is to generate a positive change in the organizations by encouraging active participation of workers in the decision-making process. The participation of workers in decisions stimulates their abilities, grants autonomy, and authority, and then, arouses innovation and adds value to the organization (Laschinger, Finegan, Shamian, \& Wilk, 2001). In organizations with high level of worker participation in decision-making, innovation practices generally yield superior results (Yang \& Konrad, 2011).

Empowerment in organizations generates high-performance indexes in terms of innovation because it involves workers in the generation of ideas and the process of organizational learning, wherein workers share ideas, process more information, and participate in decision-making. The empowerment of workers increases the probability of generating more ideas and putting them into practice (Yang \& Konrad, 2011).

Organizations that implement a system that promotes creativity will be more innovative (Kilgour, 2006). It is viable because they have a wide variety of information and knowledge for the conception of new ideas. In this regard, the participation of workers in learning and decision-making processes will result in better generation of ideas (Arthur \& Aiman-Smith, 2002).

Empowerment has a strong predictive power over innovation because it promotes the workers' commitment, which leads to greater innovation (Bhatnagar, 2014). Empowerment is positively related to innovation, both at the worker and the organization level (Cakar \& Erturk, 2010). This reflects the importance of empowerment and its relation to the process of innovation in organizations, the effect of which is not limited to the worker level, but extends to level of the entire organization.

\section{Identification with work teams}

Identification of workers with their teams can affect people's objectives, standards, and support for team goals. The way in which innovative work teams of an organization is structured reflects specialization of tasks, roles, responsibilities, and authority of workers to make decisions. This kind of work coordination fosters organizational culture and identifies with work teams (Glynn, Kazanjian, \& Drazin, 2010). Irrespective of whether workers have similar or different positions in a work team, they will have varied worker performance depending on how each one of them identifies with the work team.

The identification of workers with their work teams can also generate motivation, affection, and behavior that allow 
them to achieve their objectives within the team. There is greater motivation to innovate in the case of workers who identify strongly with their teams, (Glynn et al., 2010). People who identify with their teams are motivated to defend their identity and focus their attention on innovation work (Bantel \& Jackson, 1989), thus establishing a relationship between the identification of workers with the work team and innovation in organizations.

The effects of identification of workers with their work team stimulate learning, exchange of information, and innovation to large extent. Human resource policies can foster team cohesion. They can achieve a good sense of identity among workers. Hence, they can increase intention for innovation. Therefore, adequate recruitment and selection of members are important (Van der Vegt \& Janssen, 2003).

\section{Job performance}

The development of workers is the foundation of any organization with high performance. Workers' innovative behavior is complex in that it appears over time and occurs in three stages. In the first stage, the worker recognizes a problem. In the second stage, s/ he proposes new or adopted solutions. In the third stage, the worker shows an innovative behavior because s/he is convinced that the proposed solution can be applied to worker work, group work, organizational work (Kanter, 1988). Innovative behavior is identified through a series of stages through which the worker recognizes a problem and then proposes solutions, thereby encouraging the innovation of new models for the use and benefit of the organization (Carmeli, Meitar, \& Weisberg, 2006).

Workers can be trained to improve their innovation skills and consequently their innovative behavior (Carmeli et al., 2006). Innovation climate of an organization can generate conditions for innovation process, which is directly related to the performance of the organization (Baer \& Frese, 2003).

Empowerment leads to better performance of workers in organizations (Eylon, 1998) that facilitate innovation and improves organizational performance. If we create a culture that promotes innovation, the worker will have an optimal work process to look for different sources of knowledge and evaluate the degree of adjustment of potentially reusable knowledge (Miron et al., 2004).

The combination of creativity with application leads to innovation. The innovation process can break certain rules, especially when implementing ideas. However, quality requires adherence to rules or norms (Miron et al., 2004).

On the other hand, Douglas and Judge (2001) indicate that innovation, quality, and performance of organizations have a polarity of approaches that manifest themselves in two extremes: autonomy, which leads to innovation, and control, which is focused on details and procedures.

The innovation capacity of a worker depends on the culture and innovative climate in which s/he works. The better established the culture and climate in an organization, the better the organizational performance and worker performance will be. Creative people put their ideas and innovativeness into practice when working in an environment that favors innovation. Most researchers who have promoted innovation in organizations have witnessed growth and development that has allowed them to consolidate specific business models, such that the competition is understood and the organizations are adapted to achieve the same or new objectives (Vera, Martínez, Vera \& Cuautle 2016).

\section{Work commitment}

The management of human resources contributes to knowledge and innovation through the formation of commitment of workers, who will be willing to share their knowledge to the extent that the conditions are favorable (Carmelo-Ordaz, García-Cruz, SousaGinel \& Valle-Cabrera, 2011). The commitment of workers in the organization facilitates the generation of innovation and contributes towards the performance of the organization.

Knowledge is the first step for the generation of ideas that later transforms into innovation. Companies play an important role in that they promote more efficiency in workers as they develop an adequate environment for the production and exchange of knowledge (Rivera-Vásquez, Ortiz-Fournier, \& Flores, 2009). Coupling styles have an influence that followers perceive to be committed to their leaders and human resource systems in the processes of worker innovation, secure, anxious, and avoidant (Cerne, Batistic, \& Kenda, 2018).

Organizational commitment is defined as the degree to which a worker identifies with her/his organization and work. This leads to better performance. Therefore, it is not only important to create an adequate climate that encourages workers to share their knowledge, but also cultivate workers' commitment to the organization and its objectives (Thompson \& Heron, 2005). On the other hand, Collins and Smith (2006) found that HR management practices of high commitment contributed to the creation of a social climate in an organization. As workers were more likely to share their knowledge and generate more innovation, it can be inferred that their personal commitment and identification with the organization are decisive for knowledge creation processes. According to Alvesson (2002), companies that are successful in 
the creation and management of knowledge are those that are capable of generating a high level of knowledge.

\section{Hypotheses}

Empowerment becomes a managerial strategy that stimulates the participation of workers in decision-making, thereby promoting changes and values in the organization (Laschinger et al., 2001). Empowerment should promote a climate of adequate innovation in organizations, such that it motivates the innovative performance of workers by making them more creative and innovative, capable of taking appropriate decisions. Workers need to work in an appropriate organizational climate and environment to obtain great results.

The responsibility of making changes and decisions creates a challenge and an intrinsic motivation among the workers, which is strengthened when the work is performed within a climate of adequate innovation. It is necessary for organizations to create an innovative work environment that allows its workers to put their ingenuity into practice to make changes because workers are expected to act with some freedom and make decisions in a responsible and committed manner. Hence, the following hypothesis is proposed:

$\mathrm{H} 1$ : The empowerment of workers contributes positively to the formation of a climate for innovation in companies.

Identification of workers with their work teams should be well perceived and experienced because it affects their innovation capabilities. This is an area that requires further research in the future (Glynn et al., 2010). When the workers perceive that their work is recognized by the team and their presence is accepted, they will identify with the team, thus contributing to the formation of a better climate of innovation that ultimately becomes conducive for generating ideas and putting them into practice. Hence, the following hypothesis is proposed:

$\mathrm{H}$ 2: Identification of workers with work teams contributes positively to the formation of a climate for innovation in the companies.

Innovation is an action that can be shared by all workers in an organization. If there is an adequate environment that facilitates the development of innovative practices, it is possible for workers to develop innovation capabilities and consequently, better performance. Then, it is important to create an appropriate environment that encourages innovation and creativity. One of the components of an organization that favors innovation is the organizational innovative climate. Several studies have shown that a favorable work climate can encourage innovation. In addition, the level of creativity will depend on the motivation of the worker, while motivation in turn will depend on the organizational climate. Hence, the following hypothesis is proposed:

H3: An innovation climate in companies positively influences the performance of workers.

According to Alvesson (2002), the companies that succeed in the creation and appropriation of knowledge are those that are capable of generating a high level of commitment of workers to the organization. The commitment of workers in a continuous flow of communication has a positive effect when sharing knowledge. Consequently, creating and sharing knowledge in the organization is the basis for innovation in organizations.

Innovation-oriented culture is essential to obtain the commitment of workers, who must promote new ideas and changes that cannot be easily copied to create competitive advantages (Barney, 1986). An organizational climate that promotes innovation will generate a greater commitment of workers. In this regard, Bii and Song (2003) stated that the commitment of workers is also observed by the degree to which they identify with the objectives and results of the organization. Hence, we propose the following hypothesis:

H4: An innovation climate in companies positively influences the degree of commitment of workers.

\section{METHODOLOGY}

This research uses a quantitative research model by collecting data. We test the hypotheses by analyzing structural equations. The sample of workers was selected to obtain information from different business sectors and hierarchical levels in organizations. The results obtained were generalized, instead of adhering to a specific sector or hierarchical level.

A single questionnaire was designed to obtain information about five components: empowerment, identification with work teams, innovation climate, job performance, and work commitment. To obtain empowerment data, the survey proposed by Matthews, Díaz, and Cole (2002), which had three items, was used. To obtain the data on identification with work teams, the survey proposed by Somech, Desivilya, and Lidogoster (2009) was used, which consists of two items. The innovation climate data was developed from the scale proposed by Scott \& Bruce (1994), which consists of five items. Job performance data were expressed in three items and developed from the scale proposed by Fried, 
Ben-David, Tiegs, Avital \& Yeverechyahu (1998). Finally, the scale corresponding to work commitment consisting of five items was developed from the scale proposed by Powell and Meyer (2004).

The definition of each variable is as follows:

a. Innovation climate is the degree to which new ideas are stimulated and well received, with an emphasis on the search for new information, with creativity, openness to change, anticipation, and experimentation (Medina, Munduate, Martínez, Dorado, \& Mañas, 2004).

b. Empowerment is a motivational construct consisting of four cognitive aspects: meaning, competence, selfdetermination, and impact. These four aspects reflect an active orientation towards work (Spreitzer, 1995).

c. Identification with work teams relates to the awareness worker belongs to a certain social group. Such a sense of belongingness is valued according to the emotional significance that the group places on the worker (Tajfel, 1974).

d. d) Job performance is the series of stages of a process through which worker recognizes a problem, generates new ideas to solve it, fosters support, and produces a prototype or model for the use and/or benefit of the organization (Carmeli et al., 2006).

e. Work commitment is the degree to which people identify with the organization and commit to it. It reflects the willingness to continue working (Allen \& Meyer, 1996).

For all the cases, the Likert scale was used. To analyze the reliability of the scales, scores between 1 and 5 were assigned for each of the items in the survey. The representativeness of each number was as follows: 1: Completely disagree; 2: Disagree; 3 : Undecided; 4: Agree, and 5: Completely agree.

For the collection of data, the companies that were listed in the National Society of Industries and the Chamber of Commerce of Lima were identified. Then, the questionnaire was sent by email to 420 workers who worked in these companies, obtaining 252 responses. Out of this, 201 valid surveys were obtained. Surveys that were poorly filled were rejected (as they had missing data or were incomplete).
The informants (male and female) worked in both manufacturing and service companies. Out of this, 149 were men, representing $74.13 \%$ of the total, and 52 were women, representing $25.87 \%$. The informants' age ranged from 24 to 70 years. Majority of workers the surveyed (144 representing $71.64 \%$ ) were between 24 and 50 years of age. The remaining 57 respondents (28.35\%) were over 51 years of age. As regards the academic training of the informants, 122 respondents (60.69\%) had a master's degree or Ph.D. and 79 respondents (39.31\%) had done professional or technical studies.

To examine the validity of the measurement instrument, we follow a study model (Olmedo-Cifuentes \& Martínez-León, 2014). The following requirements were met for this: a) convergent validity, through an exploratory factor analysis of the items, to identify the elements that are grouped in each construct and (b) discriminant validity, through an analysis of correlations between constructs, to check the degree of difference between items and the way different concepts are measured. The validity of the study proposal is confirmed by the estimation of a structural equation model, which is why the measurement of the constructs is first analyzed through confirmatory factor analysis. Then, the structural model is estimated to identify the relationships among the constructs. Finally, a path analysis is developed to test the proposed hypotheses.

\section{RESULTS}

The software used to analyze the model was IBM SPSS AMOS version 24 . The model constructs were tested for reliability and validity using confirmatory factor analysis (CFA). The measurement model included 18 items that were grouped into five constructs: empowerment (EM), team identity (ID), innovation climate (CL), job performance (PF), and work commitment (AC).

\section{Quality of the measurement of the model}

Convergent validity was verified by an exploratory factor analysis of principal components. Table 1 shows the five constructs obtained:

1. Empowerment is composed of five items, whose factor loadings are $0.852,0.825,0.811,0.740$ and 0.678 .

2. Innovation climate is composed of five items, whose factor loadings are $0.847,0.831,0.758$, 0.662 and 0.606. 
3. Job performance is composed of three items, whose factor loadings are 0.889, 0.854, and 0.773.

4. Empowerment is composed of three items, whose factor loadings are $0.845,0.822$ and 0.775

5. Team identity is composed of two items, whose factor loadings are 0.862 and 0.863 .

The results obtained in each item show highly reasonable factor loadings, which confirm the justification and unidimensionality of the five constructs.

Table 1. Exploratory factor analysis: rotated component matrix

\begin{tabular}{|c|c|c|c|c|c|c|}
\hline \multirow{2}{*}{$\begin{array}{c}\text { Items } \\
\text { (KMO:0.856; Barlett sphericity test }=0.000 \\
\text { Total variance explained: } 79.34 \%)\end{array}$} & \multirow{2}{*}{ Item code } & \multicolumn{5}{|c|}{ Components } \\
\hline & & $\begin{array}{l}\text { Work } \\
\text { commitment }\end{array}$ & $\begin{array}{l}\text { Innovation } \\
\text { climate }\end{array}$ & $\begin{array}{l}\text { Job } \\
\text { performance }\end{array}$ & Empowerment & $\begin{array}{l}\text { Identification } \\
\text { with work } \\
\text { teams }\end{array}$ \\
\hline The organization problem es also my problem & $\mathrm{AC} 2$ & 0.852 & 0.078 & -0.005 & 0.214 & 0.128 \\
\hline Working in this organization means a lot to me & $\mathrm{AC}_{3}$ & 0.825 & 0.256 & 0.151 & 0.022 & 0.062 \\
\hline I feel part of this organization & $\mathrm{AC}_{5}$ & 0.811 & 0.221 & 0.101 & 0.173 & 0.225 \\
\hline $\begin{array}{l}\text { I would like to continue working in this } \\
\text { organization }\end{array}$ & $\mathrm{AC}_{1}$ & 0.740 & 0.096 & 0.421 & 0.155 & 0.006 \\
\hline I feel like family in this organization & $\mathrm{AC}_{4}$ & 0.678 & 0.350 & 0.196 & 0.190 & 0.319 \\
\hline $\begin{array}{l}\text { This organization gives me time to look for new } \\
\text { ideas }\end{array}$ & $\mathrm{CL}_{5}$ & 0.266 & 0.847 & -0.002 & 0.247 & 0.119 \\
\hline We have enough time to carry out new ideas & CL4 & 0.141 & 0.831 & 0.078 & 0.151 & -0.056 \\
\hline The system promotes and rewards innovation & CL6 & 0.121 & 0.758 & -0.037 & 0.398 & 0.083 \\
\hline The organization encourages creativity & CL1 & 0.271 & 0.662 & 0.208 & 0.303 & 0.385 \\
\hline $\begin{array}{l}\text { The organization respects the creative capacity } \\
\text { at work }\end{array}$ & $\mathrm{CL} 2$ & 0.326 & 0.606 & 0.265 & 0.314 & 0.360 \\
\hline $\begin{array}{l}\text { The worker is able to find the problem and } \\
\text { solve it }\end{array}$ & $\mathrm{PF}_{3}$ & 0.139 & -0.037 & 0.889 & 0.008 & 0.129 \\
\hline $\begin{array}{l}\text { The worker performs the work with precision } \\
\text { and quality }\end{array}$ & PF2 & 0.115 & 0.147 & 0.854 & 0.020 & 0.130 \\
\hline The worker is satisfied with his performance & PF4 & 0.186 & 0.076 & 0.773 & 0.142 & 0.269 \\
\hline Employees have a voice and vote for work rules & $\mathrm{EM}_{4}$ & 0.134 & 0.271 & 0.043 & 0.845 & 0.088 \\
\hline $\begin{array}{l}\text { Employees have a voice and vote for company } \\
\text { policies }\end{array}$ & EM5 & 0.155 & 0.324 & 0.028 & 0.822 & 0.061 \\
\hline $\begin{array}{l}\text { Employees have a voice and vote for their work } \\
\text { responsibilities }\end{array}$ & $\mathrm{EM}_{3}$ & 0.249 & 0.269 & 0.136 & 0.775 & 0.199 \\
\hline I like to do my work as a team & ID2 & 0.168 & 0.173 & 0.205 & 0.082 & 0.863 \\
\hline I like work teams & $\mathrm{ID}_{3}$ & 0.190 & 0.043 & 0.260 & 0.163 & 0.862 \\
\hline Variance explained & & $19.96 \%$ & $18.62 \%$ & $14.54 \%$ & $14 \cdot 51 \%$ & $11.77 \%$ \\
\hline
\end{tabular}

Extraction method: Main component analysis. Rotation method: Varimax with Kaiser normalization

${ }^{a}$ The rotation has turned into five iterations

Source: Authors. 
After the exploratory analysis, we performed a confirmatory factor analysis to obtaining acceptable results from the model. Table 2 shows the reliability of the scale data, both the Cronbach's a and composite reliability values. These values are above the recommended value of 0.7 for all constructs (Hair, Black, \& Anderson, 2010). In addition, average variance extracted (AVE) results are shown, which are above the minimum recommended value of 0.5 for all constructs (Hair et al., 2010).

Table 2. Confirmatory factor analysis results

\begin{tabular}{|c|c|c|c|c|c|c|}
\hline Construct & Item & $\begin{array}{l}\text { Estandardised } \\
\text { factor loading }\end{array}$ & $\begin{array}{c}\text { Critical ratio } \\
\text { (C.R.) }\end{array}$ & $\begin{array}{c}\text { Reliability } \\
\text { (Cronbach's alfa) }\end{array}$ & $\begin{array}{l}\text { Composite } \\
\text { reliability }\end{array}$ & $\begin{array}{c}\text { Average variance } \\
\text { extracted (AVE) }\end{array}$ \\
\hline \multirow{3}{*}{ Work commitment } & $\mathrm{AC} 2$ & 0.843 & & \multirow{3}{*}{0.897} & \multirow{3}{*}{0.919} & \multirow{3}{*}{0.697} \\
\hline & $\mathrm{AC}_{3}$ & 0.753 & 11.772 & & & \\
\hline & $\mathrm{AC}_{4}$ & 0.942 & 11.470 & & & \\
\hline \multirow{4}{*}{ Innovation climate } & CL6 & 0.730 & & \multirow{4}{*}{0.907} & \multirow{4}{*}{0.903} & \multirow{4}{*}{0.658} \\
\hline & $\mathrm{CL}_{5}$ & 0.789 & 13.987 & & & \\
\hline & $\mathrm{CL} 4$ & 0.601 & 8.796 & & & \\
\hline & $\mathrm{CL} 2$ & 0.956 & 10.691 & & & \\
\hline Job performance & $\mathrm{PF} 2$ & 0.809 & 11.634 & 0.849 & 0.852 & 0.658 \\
\hline \multirow{3}{*}{ Empowerment } & $\mathrm{EM}_{5}$ & 0.843 & & \multirow{3}{*}{0.876} & \multirow{3}{*}{0.877} & \multirow{3}{*}{0.704} \\
\hline & $\mathrm{EM}_{4}$ & 0.828 & 13.399 & & & \\
\hline & $\mathrm{EM}_{3}$ & 0.846 & 13.746 & & & \\
\hline \multirow{2}{*}{ Identification with work teams } & $\mathrm{ID}_{3}$ & 0.902 & & \multirow{2}{*}{0.874} & \multirow{2}{*}{0.875} & \multirow{2}{*}{0.778} \\
\hline & ID2 & 0.862 & 12.547 & & & \\
\hline
\end{tabular}

Source: Authors.

As regards the values of model fit summary, all the indexes exceed the limits recommended by Hair et al. (2010). The $x^{2}$ ratio was 2.168 (below 3), the RMSEA was 0.076 (below 0.08), and the other indexes, CFI, NFI, IFI, and TLI, were 0.953, 0.918, 0.954, and 0.934, respectively (which are above the recommended value of 0.9). Similar recommended indices were taken from RodriguezLopez and Diz-Comesaña (2016)

Then, the discriminant validity correlations were analyzed (see Table 3). As the values obtained are below the recommended value of 0.8 (Hair et al., 2010), the discriminant validity was confirmed.

Table 3. Means, standard deviation, and correlations between constructs

\begin{tabular}{|c|c|c|c|c|c|c|c|c|}
\hline \multirow{2}{*}{ Construct } & \multirow{2}{*}{ Code } & \multirow{2}{*}{ Mean } & \multirow{2}{*}{ Standard deviation } & \multicolumn{5}{|c|}{ Correlations } \\
\hline & & & & $A C$ & $\mathrm{CL}$ & PF & EM & ID \\
\hline Work commitment & $A C$ & 4.214 & 0.767 & 1.000 & & & & \\
\hline Job performance & $\mathrm{PF}$ & 4.275 & 0.620 & $0.425^{* *}$ & $0.283^{* *}$ & 1.000 & & \\
\hline Empowerment & EM & 3.083 & 0.985 & $0.458^{\star *}$ & $0.662^{\star *}$ & $0.217^{* \star}$ & 1.000 & \\
\hline
\end{tabular}

*** The correlation is significant at the 0.01 level (bilateral).

Source: Authors. 


\section{Test of hypotheses}

Figure 1 shows the study model with the significant estimates for each relationship, which allow the accepting of the hypotheses. To test the proposed hypotheses, we develop a path analysis. The results of the proposed model are shown in Table 4 . The fitted model is significant with the following values: model fit x2: 1.592; CFI: 0.943; IFI: 0.944, TLI: 0.929, and RMSEA: 0.076.

Hypothesis $\mathrm{H}_{1}$ states that empowerment contributes positively in the formation of innovation climate, hypothesis $\mathrm{H}_{2}$ states that identification with work teams contributes positively in the formation of innovation climate. The results indicate that the relationship between both empowerment and innovation climate and identification with work teams and innovation climate are positive and significant $(B=0.604, P<0.05$ and $B=0.343 ; P<0.05$, respectively). Therefore, hypotheses $\mathrm{H}_{1}$ and $\mathrm{H}_{2}$ are supported.

Hypotheses 3 and 4 state that the innovation climate variable positively influences the variables job performance and work commitment. The results indicate that the relationship between innovation climate and job performance and innovation climate and work commitment are positive and significant $(B=$ $0.457, \mathrm{P}<0.05$ and $\mathrm{B}=0.702, \mathrm{P}<0.05$, respectively). Therefore, hypotheses $\mathrm{H}_{3}$ and $\mathrm{H}_{4}$ are supported.

Figure 1. Results of the research model

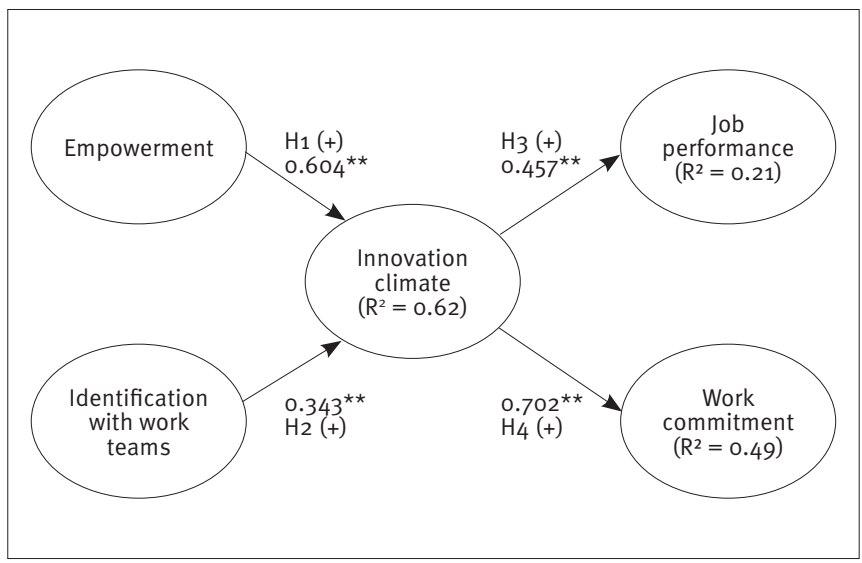

**P$<0.05$

\section{Table 4. Path analysis results}

\begin{tabular}{|c|c|c|c|c|c|}
\hline Regression & Estimate & $\begin{array}{c}\text { Standard } \\
\text { error }\end{array}$ & CR & $\mathbf{P}^{*}$ & Hypotheses \\
\hline Empowerment $\rightarrow$ Innovation climate & 0.604 & 0.105 & 5.531 & 0.00 & $\mathrm{H}_{1}(+)$ \\
\hline Identification with work teams $\rightarrow$ Innovation climate & 0.343 & 0.133 & 3.684 & 0.00 & $\mathrm{H}_{2}(+)$ \\
\hline Innovation climate $\rightarrow$ Job performance & 0.457 & 0.080 & 3.828 & 0.00 & $\mathrm{H}_{3}(+)$ \\
\hline
\end{tabular}

Model Fit $X^{2}$ : 1.592; CFI:0.943; IFI:0.944, TLI:0.929; RMSEA: 0.076

Source: Authors.

\section{DISCUSSION}

The authors' theories that supported our proposed research model were first reviewed, then, the data were collected using the measuring instrument. Finally, the results were statistically analyzed by means of an exploratory factorial analysis, confirmatory analysis, and analysis of structural equations.

The statistical analysis confirms hypothesis $1\left(\mathrm{H}_{1}\right)$, that is, empowerment influences the formation of innovation climate. This implies that if companies establish empowerment programs for their workers they can make workers more motivated and proactive. This will improve communication between them and generate the necessary conditions to establish a climate of innovation in companies. In this regard, Singer and Donoso (2005) state that workers can not only make decisions, but also improve communication, proactiveness, and ability to implement novel ideas through empowerment.

As regards hypothesis $2\left(\mathrm{H}_{2}\right)$, it has been verified that identification with work teams contributes positively towards forming innovation climate. This implies that workers' capacity to identify with work teams is more likely to form an organizational culture of innovation. Studies such as by Bantel and Jackson (1989) argue that people who identify with their teams tend to be more motivated to defend the identity of the team and willing to participate in innovation work. The roles, responsibilities, and authority given to workers form the identification with work team, which influences organizational culture (Glynn et al., 2010).

Hypothesis $3\left(\mathrm{H}_{3}\right)$ was confirmed to be positive. It was found that innovation climate positively influences job performance. This implies that a culture of beliefs and values 
aimed at maintaining an adequate innovation climate influences the behavior and worker performance of workers. In this regard, West (2002) indicates that when the culture and climate of organizations support innovation, the performance of innovation practices improves.

Hypothesis $4\left(\mathrm{H}_{4}\right)$ was confirmed to be positive. It was found that innovation climate positively influences work commitment. This implies that a culture of beliefs and values oriented to innovation promotes the commitment of workers to generate new ideas, processes, and products. Workers enter a process of knowledge and information exchange to generate new products, also known as innovation (Lin et al., 2014). Companies with high participation of workers contribute to the generation of commitment. It also makes workers willing to overcome their natural resistance to share their knowledge (Carmelo-Ordaz et al., 2011).

\section{CONCLUSIONS, LIMITATIONS, AND FUTURE RESEARCH}

The results of the study indicate that companies need to operate in a climate suitable for creativity and innovation to occur. Innovation climate is a component of the organizational process that is influenced by variables like empowerment and identification with work teams and it is in turn influences other variables like job performance and work commitment.

Based on the verification of the hypothesis, empowerment and identification of the worker with their teams help to create an adequate innovation climate, thus producing positive results for the organization in the form of fulfillment of the objectives of the work teams and greater commitment from the workers.

Consequently, companies should promote actions to empower workers and enable them to identify with their teams to form an adequate organizational climate that strengthens innovation climate. Innovation climate will help generate greater work commitment among workers, which in turn, will yield positive results. In this regard, Ekvall (1996) argues that the climate influences the processes that yield innovative results and as such, organizations should maintain an adequate climate to achieve the objectives. Therefore, managers should give importance to the creation of an innovation climate, especially if the organization's purpose is to conduct innovation activities.

Given that the study was conducted with a sample of companies from both the manufacturing and services sectors, one limitation of the study is that it did not produce results for each sector. This is because each sector may have different ways of managing its innovation climate. Another limitation of the study is that the survey does not indicate at its onset whether the companies are managing innovation. The perception of the informants could be different in companies that do not conduct innovation management.

The analysis of companies that are carrying out innovation management is proposed as a future line of research to establish the presence of innovation climate and its extent. Similarly, new studies can be conducted on specific sectors, for example, manufacturing, services, and mining. Another line of future research is the investigation of other variables that influence innovation climate as well as other variables that are influenced by innovation climate. The model of this study can be tested in companies with different types of organizational culture to verify or generalize the results of the study. Finally, the relationship between innovation climate and organizational culture can be explored, the results of which can help the people responsible for creating appropriate working climates.

\section{REFERENCES}

Allen, N., \& Meyer, J. (1996). Affective, continuance and normative commitment to the organization: An examination of construct validity. Journal of Vocational Behavior, 49(3) 252-276. doi: 10.1006/ jvbe.1996.0043

Alvesson, M. (2002). Social identity and the problem of loyalty in knowledge-intensive companies. Journal of Management Studies, 37(8), 1101-1123. doi: 10.1111/1467-6486.00218

Ancarani, A., Mauro, C., \& Giammanco, M. (2019). Linking organizational climate to work engagement: A study in the healthcare sector. International Journal of Public Administration, 42 (7), 547-557. doi:10 $.1080 / 01900692.2018 .1491595$

Arguello, M. B., \& Quintanilla, C. J. (2017). Análisis de los modelos para determinar la relación entre liderazgo e innovación. Revista Publicando, 12(2), 921-930. Retrieved on: https://revistapublicando. org/revista/index.php/crv/article/view/1149

Arthur, J. \& Aiman-Smith, L. (2001). Gainsharing and organizational learning: An analysis of employee sugestions over time. Academy of Management Journal, 44(4) 737-754. doi: 10.5465/3069413

Baer, M., \& Frese, M. (2003). Innovation is not enough: Climates for initiative and psychological safety, process innovations, and firm performance. Journal of Organizational Behavior, 24(1), 45-68. doi 10.1002/job.179

Bain, P., Mann, L., \& Pirola-Merlo, A. (2001). The innovation imperative: The relationships between team climate, innovation, and performance in research and development teams. Small Group Research, 32(1), 55-73. doi: 10.1177/104649640103200103

Barney, J. (1986). Organizational Culture: Can It Be a Source of Sustained Competitive Advantage?. Academy of Management Review, 11(3), 656-665. doi: 10.5465/amr.1986.4306261 
Barreto, J. R., \& Petit, E. E. (2017). Modelos explicativos del proceso de innovación tecnológica en las organizaciones. Revista Venezolana de Gerencia, 22(79), 387-405. http://www.redalyc.org/articulo. oa?id=29055964004

Bantel, K., \& Jackson, S. (1989). Top management and innovations in banking: Does the composition of the top team make a difference? Strategic Management Journal, 10, 107-124. doi: 10.1002/ smj.4250100709

Bhatnagar, J. (2014). Mediator analysis in the management of innovation in Indian knowledge workers: The role of perceived supervisor support, psychological contract, reward and recognition and turnover intention. The International Journal of Human Resource Management, 25(10), 1395-1416. doi: 10.1080/09585192.2013.870312

Bii, H. Van der, \& Song, M. (2003). An empirical investigation into the antecedents of knowledge dissemination at the strategic business unit level. Journal of Product Innovation Management, 20(2), 163-179. doi: 10.1111/1540-5885.2002008

Cakar, N. D. \& Erturk, A. (2010). Comparing innovation capability of small and medium-sized enterprises: Examining the effects of organizational culture and empowerment. Journal of Small Business Management, 48(3), 325-359. doi: 10.1111/j.1540-627x.2010.00297.x

Carmeli, A., Meitar, R., \& Weisberg, J. (2006). Self-leadership skills and innovative behavior at work. Journal International of Manpower, 27(1), 75-90. doi: 10.1108/014137720610652853

Carmelo-Ordaz, C., García-Cruz, J., Sousa-Ginel, E. \& Valle-Cabrera, R. (2011). The influence of human resource management on knowledge sharing and innovation in Spain: The mediating role of affective commitment. International Journal of Human Resource Management, 22, 1442-1463. doi: 10.1080/09585192.2011.561960

Cerne, M., Batistic, S., \& Kenda, R. (2018). HR systems, attachment styles with leaders, and the creativity-innovation nexus. Human Resource Management Review, 28(3), 271-288. doi: 10.1016/j. hrmr.2018.02.004

Collins, C., \& Smith, K. (2006). Knowledge exchange and combination: The role of human resource practices in the performance of hightechnology firms. Academy of Management Journal, 49(3), 544-560. doi: 10.5465 /amj.2006.21794671

Douglas, T., \& Judge, W. (2001). Total quality management implementation and competitive advantage: The role of structural control and exploration. Academy of Management Journal, 44(1), 158 169. doi: $10.5465 / 3069343$

Dutton, J., Dukerich, J., \& Harquail, C. (1994). Organizational images and member identification. Administrative Science Quarterly, 39(2), 239263. doi: $10.2307 / 2393235$.

Ekvall, G. (1996). Organizational climate for creativity and innovation. European Journal of Work and Organizational Psychology, 5(1), 105123. doi:10.1080/13594329608414845

Eylon, D. (1998). Understanding empowerment and resolving its paradox: Lessons from Mary Parker Follett. Journal of Management History, 4(1), 16-28. doi: 10.1108/13552529810203905

Fried, Y., Ben-David, H. A., Tiegs, R. B., Avital, N. \& Yeverechyahu, U. (1998). The interactive effect of role conflict and role ambiguity on job performance. Journal of Occupational and Organizational Psychology, 71(1), 19-27. doi: 10.1111/j.2044-8325.1998.tboo659.x
Friedrich, T., \& Zhong, M. (2017). Collective leadership as a facilitator of innovation. Handbook of research on leadership and creativity. Edward Elgar publishing. 297-315. doi: 10.4337/9781784715465.00022

Glynn, M., Kazanjian, R., \& Drazin, R. (2010). Fostering innovation in complex product development settings: The role of team member identity and interteam interdependence. Journal of Product Innovation Management, 27(7), 1082-1095. doi: 10.1111/j.1540-5885.2010.00772.x

Gonzales-Roma, V., \& West, M. (2004). Agreeing to disagree: Climate strength and innovation in work teams. Unpublished manuscript. University of Valencia, Spain

Hair, J., Black, W., \& Anderson, R. (2010). Multivariate data analysis. New York, USA: Pearson.

Isaksen, S., \& Lauer, K. (2002). The climate for creativity and change in teams. Creativity and Innovation Management, 11(1), 74-86. doi: $10.1111 / 1467-8691.00238$

Isaksen, S. G. (2007). The climate for transformation: Lessons for leaders. Creativity \& Innovation Management, 16(1), 3-15. doi: 10.1111/j.1467-8691.2007.00415.x

Kanter, R. (1988). When a thousand flowers bloom: Structural, collective, and social conditions for innovation in organizations. Research in Organizational Behavior, 10, 169-211. Retrieved on: https://web-a-ebscohost-com.esan.idm.oclc.org/ehost/detail/ detail?vid=19\&sid=a2f5754e-9acd-4efa-8439-ce8db1d5349c\%40se ssionmgr4006\&bdata =Jmxhbmc9ZXMmc2loZT1laG9zdC1saXZl\#db= bth $\& A N=6815426$

Kilgour, M. (2006). Improving the creative process: Analysis of the effects of divergent thinking techniques and domain specific knowledge on creativity. International Journal of Business and Society, 7(2), 79-107. Retrieved on: https://researchcommons.waikato.ac.nz/bitstream/ handle $/ 10289 / 1872 /$ kilgour? sequence $=1$

King, E. B., De Chermont, K., West, M., Dawson, J. F., \& Hebl, M. R. (2007). How innovation can alleviate negative consequences of demanding work contexts: The influence of climate for innovation on organizational outcomes. Journal of Occupational and Organizational Psychology, 80, 631-645. doi:10.1348/096317906X171145

Laschinger, H., Finegan, J., Shamian, J., \& Wilk, P. (2001). Impact of structural and psychological empowerment on job strain in nursing work settings: Expanding Kanter's Model. Journal of Nursing Administration, 31(5), 260-272. Retrieved on: https://journals.Iww. com/jonajournal/Abstract/2001/05000/Impact_of_Structural_and_ Psychological_Empowerment.6.aspx

Lin, P. C., Ho, H. Y., \& Lu, M. H. (2014). Efectos sobre la gestión del conocimiento y la cultura corporativa en el clima de innovación organizativa. Revista Internacional de Sociología, 72, 43-55. doi:10.3989/ris.2013.08.09

Matthews, R., Díaz, W., \& Cole, S. (2002). The organizational empowerment scales. Personnel Review, 32, 397-318. doi: $10.1108 / 00483480310467624$

Medina, F., Munduate, L., Martínez, I., Dorado, M., \& Mañas, M. (2004). Efectos positivos de la activación del conflicto de tarea, sobre el clima de los equipos de trabajo. Revista de Psicología Social, 19(1), 3-15. doi: 10.1108/00483480310467624

Miron, E., Erez, M., \& Naveh, E. (2004). Do personal characteristics and cultural values that promote innovation, quality, and efficiency compete or complement each other? Journal of Organizational Behavior, 25(2), 175-199. doi: 10.1002/job.237 
Mol, M. \& Birkinshaw, J. (2009). The sources of management innovation: When firms introduce new management practices. Journal of Business Research, 62(12), 1269-1280. doi: 10.1016/j.jbusres.2009.01.001

Montes, F. L., Moreno, A. R., \& Fernández, L. M. (2004). Assessing the organizational climate and contractual relationship for perceptions of support for innovation. International Journal of Manpower, 25, 167180. doi: $10.1108 / 01437720410535972$

Olmedo-Cifuentes, I., \& Martínez-León, I. (2014). Influence of management style on employee views of corporate reputation: Application to audit firms. BQR Business Research Quarterly, 17(4), 223-241. doi: 10.1016/j.brq.2013.08.001

Patterson, M., West, M., Shackleton, V., Dawson, J., Lawthom, R., Maitlis, S., \& Wallace, A. (2005). Validating the organizational climate measure: Links to managerial practices, productivity and innovation. Journal of Organizational Behavior, 26(4), 379-408. doi: 10.1002/ job.312

Powell, D., \& Meyer, J. (2004). Side-bet theory and the three-component model of organizational commitment. Journal of Vocational Behavior, 65(1), 157-177. doi: 10.1016/Soo01-8791(03)00050-2

Rivera-Vásquez, J., Ortiz-Fournier, L., \& Flores, F. (2009). Overcoming cultural barriers for innovation and knowledge sharing. Journal of Knowledge Management, 13(5), 257-270. doi: $10.1108 / 13673270910988097$

Rodriguez-Lopez, N., \& Diz-Comesaña, M. (2016). The mediated effect of formal and informal control on governance forms. RAE-Revista de Administração de Empresas, 56(6), 655-667. doi: 10.1590/soo34759020160607

Sánchez, A., Quintero, M. L., Sánchez, R., Fierro, E., \& García, C. (2017). Gobernanza del emprendimiento social: Especificación de un modelo para el estudio de la innovación local. Nómadas. Critical Journal of Social and Juridical Sciences, 51(2), 51-73. doi: 10.5209/ NOMA. 54863

Scott, G. S. \& Bruce, R. A. (1994). Determinants of innovative behavior: A path model of individual innovation in the workplace. Academy of Management Journal, 37(3), 580-607. doi: 10.5465/256701

Singer, M., \& Donoso, P. (2005). Un caso de empoderamiento en la industria química. Revista ABANTE, 8(1), 3-24. Retrived on: http:// www.abante.cl/files/ABT/Contenidos/Vol-8-N1/Singer.pdf

Somech, A., Desivilya, H., \& Lidogoster, H. (2009). Team conflict management and team effectiveness: The effects of task interdependence and team identification. Journal of Organizational Behavior, 30(3), 359-378. doi: 10.1002/job.537
Souto, J. (2015). Gestión de una cultura de innovación basada en las personas. Journal of Technology Management \& Innovation, 10(3), 60-65. doi: 10.4067/S0718-27242015000300007

Spreitzer, G. (1995). Psychological, empowerment in the workplace: Dimensions, measurement and validation. Academy of Management Journal, 38(5), 1442-1465. doi: 10.2307/256865

Tajfel, H. (1974). Social identity and intergroup behavior. Social Science Information, 13, 65-93. doi: 10.1177/053901847401300204

Tan, H. C., \& Ho, J. A. (2015). The influence of communication, empowerment and trust on organizational ethical climates. International Journal of Economics \& Management, 9, 2344. Retrieved on: https://pdfs.semanticscholar.org/53d9/ b8e7d5089290e5a7e1d547126a40eb8foe4b.pdf

Thompson, M., \& Heron, P. (2005). Management capability and high-performance work organization. The International Journal of Human Resource Management, 16(6), 1029-1048. doi: $10.1080 / 09585190500120806$

Vaccaro, I., Jansen, J., Van Den Bosch, F. \& Volberda, H. (2012). Management innovation and leadership: the moderating role of organizational size. Journal of Management Studies, 49(1), 28-51. doi: 10.1111/j.1467-6486.2010.00976.x

Van Der Vegt, G. S., \& Bunderson, J. S. (2005). Learning and performance in multidisciplinary teams: The importance of collective team identification. Academy of management Journal, 48(3), 532-547. doi: 10.5465/amj.2005.17407918

Van derVegt, G. S., \& Janssen, O. (2003). Joint impact of interdependence and group diversity on innovation. Journal of management, 29(5), 729-751. doi: 10.1016/s0149-2063_03_00033-3

Vera, M. A., Martínez, R., Vera, G. \& Cuautle, A. (2016). Responsabilidad social empresarial y los profesionales de las ciencias económicoadministrativas. Revista Global de Negocios, 4(7), 1-12. Retrieved on: https://www.theibfr.com/download/rgn/2016-rgn/rgn-v4n7-2016/ RGN-V4N7-2016.pdf\#page $=3$

West, M. (2002). Sparkling fountains or stagnant ponds: An integrative model of creativity and innovation implementation in work groups. Applied psychology, 51(3), 355-386. doi: 10.1111/1464-0597.00951

Yang, Y., \& Konrad, A. (2011). Diversity and organizational innovation: The role of employee involvement. Journal of Organizational Behavior, 32(8), 1062-1083. doi: 10.1002/job.724

Yasini, P. (2016). Specific characteristics of innovation management process. International Journal of Organizational Leadership, 5(2), 162-171. doi: $10.33844 /$ ijol.2016.60406

\section{AUTHORS' CONTRIBUTIONS}

The authors declare that the conceptualization and theoretical-methodological construction, as well as, theoretical review (literature survey) was coordinated by Manuel Fernando Montoya Ramírez and Jhony Ostos. The Data Collection was conducted by Manuel Fernando Montoya Ramírez and Data Analysis by Jhony Ostos and Arturo Rodolfo Saenz Arteaga. They contributed equally in the writing and final review the article. 